\title{
The use of dynamic games in the development of motor skills among children with special educational needs
}

\author{
Bogdan Constantin UNGUREAN ${ }^{1}$, Adrian COJOCARIU ${ }^{2}$, Alexandru OPREAN ${ }^{3}$
}

\begin{abstract}
Dynamic games can contribute to the growth of the efficiency, motivation in developing the quality of the movement for children with special educational needs, if the psycho-physiological particularities in the training of these children are followed, if the most efficient methods and means of achieving the purpose, a good staging of the training process with a proper dosage of the effort and with a growth of the quality in organizing and leading the activity are used.

The purpose of the paper was to select among the movement games the most efficient ones for the developing of the movement quality, to explain them during physical education classes and the obtained results to demonstrate their efficiency in achieving the goal. To achieve this study, we started from the following hypothesis: we assume that by predominantly using the dynamic games during the physical education classes we can achieve a growth of the indices of the movement quality in children with special educational needs.

Methods and materials: In this aspect, we built a set of tests (Long jump, speed running - 50 meters, Shuttle run 5x10m, throwing rounders ball) with which we operated in two periodical assessments during an entire school year.

The place of this study was at the "St. Andrew" Inclusive Education Scholar Center from Gura Humorului. These two classes of students had one weekly hour of physical education in their timetable.

Results and conclusions: Using the results of the physical assays as reference elements, the accumulations of the pupils during the research concerning the movement quality had emerged.

In conclusion, if age and individual particularities of the pupils, didactical canons are followed, if proper preparatory games are selected and the planned activity happens in a systematic way with responsibility, the results won't hesitate to appear.

Key words: dynamic games, special educational needs
\end{abstract}

\section{Rezumat}

Jocurile dinamice pot contribui la creșterea eficienţei, motivaţiei în dezvoltarea calităților motrice la copiii cu cerințe educaționale speciale, dacă se respectă particularităţile psiho-fiziologice de pregătire ale acestor copiilor, dacă se utilizează cele mai eficiente metode şi mijloace de realizare, o bună etapizare a procesului de pregătire cu dozare a efortului adecvată şi cu o creștere a calităţii în organizarea şi conducerea activităţii.

Scopul lucrării a fost acela de a selecta din cadrul jocurilor de mișcare, pe cele mai eficiente pentru dezvoltarea calităților motrice, de a le explica în cadrul orelor de educaţie fizică, iar rezultatele obţinute să demonstreze eficienţa lor în realizarea finalităţilor. În realizarea acestui studiu, am pornit de la următoarea ipoteză: presupunem că prin utilizarea cu preponderență a jocurilor dinamice în cadrul lecției de educație fizică vom obține o creștere a indicilor calităților motrice la copiii cu cerințe educaționale speciale.

Material și metode: În acest sens, am alcătuit o baterie de teste (Săritura în lungime de pe loc, Alergare de viteză - 50 m, Naveta 5x10 m, Aruncarea mingii de oina de pe loc)cu care am operat în cadrul a două testări periodice pe parcursul unui an şcolar.

\footnotetext{
${ }^{1}$ Lecturer, "Alexandru Ioan Cuza” University of Iaşi. Romania, Faculty of Physical Education and Sport, e-mail: bungurean@yahoo.com

${ }^{2}$ Assoc. Prof., "Alexandru Ioan Cuza" University of Iaşi, Romania, Faculty of Physical Education and Sport

${ }^{3}$ Lecturer, "Alexandru Ioan Cuza" University of Iaşi, Romania, Faculty of Physical Education and Sport
} 
Locul acestui studiu a fost la Centrul Școlar de Educaţie Incluzivă „Sf. Andrei” Gura Humorului.Aceste două clase au avut în orarul şcolar câte o oră de educaţie fizică săptămânal.

Rezultate și concluzii: Folosind ca elemente de referinţă rezultatele probelor fizice, au ieșit în evidenţă acumulările elevilor pe perioadă desfăşurării cercetării în privinţa calităților motrice.

În concluzie, dacă se respectă particularităţile de vârstă şi individuale ale elevilor, principiile didactice, dacă se selectează jocuri pregătitoare adecvate, iar activitatea planificată se desfăşoară în mod sistematic cu simţ de răspundere, rezultatele nu vor ezita să apară.

Cuvinte cheie: jocuri dinamice, cerințe educaționale speciale 


\section{Introduction}

The history of scientific approach to mental deficiency has been conducted, within the Romanian literature, by authors such as Ş. Ionescu [4], Arcan and Ciumăgeanu [1]. Furthermore, a more than comprehensive perspective on this topic can be found in the work called "Debilităţile mintale" [Mental Debilities] [4].

The analysis of various types of disabilities (mental, physical, sensory, of language or associated) involves an interdisciplinary approach, using concepts in the field of general medicine, psychiatry, neurology, psychology, pedagogy, genetics, sociology, etc [2].

Scientific literature uses a series of synonymous terms in order to designate mental disability, among which the most frequent ones are the following: mental deficiency, mental disability, mental delay, mental backwardness, oligophrenia, mental retardation, mental insufficiency, mental undernormality, intellectual retardation, handicap mental, mental debility, amentia, adaptive behaviour alteration, etc.

The definition of SEN can also be analysed from the perspective of the phrase "children with special needs". Lately, in Romania discussions have used the phrase "children with special needs", thus avoiding "persons or children with handicap". Persons with special needs can be persons with certain disabilities, more or less serious.

Dynamic games can contribute to increasing efficiency, motivation in the development of motor skills among children with special educational needs, if you respect the psycho-physiological training particularities of these children, if you use the most efficient methods of means of performance, a good phasing of the training process with a proper dosing of the effort and with an increase in quality concerning the organization and administration of the activity [3].

We have discussed the competences of specialists in this field, the fragile material base, but mostly the lack of a real social protection for students with educations issues. This imposes a creative reapproach to the issues caused by the rehabilitation of children with mental disability, an aspect that determined me to approach this topic. I started from the assumption that play, as a form of mental and physical, behavioural and relational manifestation, may exercise - when organized rigorously and directed creatively - significant influences in the activity of socio-professional rehabilitation and reintegration of the student with special educational needs.

In order to conduct the study, I started from the following hypothesis: I assume that by using mainly dynamic games within the physical education class, I will obtain an increase in indices of motor skills among children with special educational needs.

The purpose of the paper was to select from among the movement games the most efficient ones for the development of motor skills, to explain them within physical education classes; the results obtained should demonstrate their efficiency in the achievement of finalities.

In order to validate the determined hypothesis, I had to cover several phases:

-Studying the topic in the scientific literature; -Choosing the samples comprised in the research; -Getting to know the level of motor and mental development of the sample comprised in the research;

-Determining the stages or organizing and conducting the research;

-Elaborating the assessment criteria, the initial and final testing of the sample comprised in the research;

-Processing the initial and final data, graphic representation;

\section{Material and methods}

This study was conducted at the "Sf. Andrei" School of Gura Humorului, Suceava County, and the subjects were selected from two sixth grades within this school. These two grades had two physical education classes per week scheduled in their curriculum.

Taking into account the relatively short time allocated to the development of motor skills, the numerous tasks to be solved within every lesson, the training level of each grade, the age to which the instruction means addresses, the QI level, it is necessary to choose means and methods with precise orientation and maximum efficiency. There is a multitude of means to be used, but a selection should be made in terms of structure and functionality. 
Exercises must be grouped into complexes, by determining a precise quantification for each year of study, which will grow from one period to another, due to the increase in students' exercise capacity. In order to write this paper, I conducted a constatative study, which allowed me to solve the paper tasks on scientific bases. In this respect, I elaborated a battery of tests that I used within two periodical tests throughout a school year.

\section{Control tests/events}

1. Standing long jump

* Standing behind a line, soles apart at shoulder level, take-off by bending and extending legs while swinging the arms;

* energetic impulsion, long jump and landing on both feet;

* the jump length was measured from the line to the heels;

2. Speed run $-50 \mathrm{~m}$

* executed in a straight line on a flat floor;

* the start and finish lines were drawn;

* the stopwatch was turned on upon the movement of the rear leg;

* the time in seconds and second fractions was recorded;

3. $5 \times 10$ m relay

* executed on a flat, non-slippery surface;

* two parallel lines were drawn at a distance of 10 $\mathrm{m}$;

* the performer was placed behind a line, and on the signal he started running towards the opposite line, he crossed it with both feet and returned to the start line, thus covering five times the distance of 10 $\mathrm{m}$;

4. Standing throw of the tennis ball

* the throw was executed using one hand, above the shoulder, without take-off;

*the length of the throw was recorded in meters (the best result out of two attempts);

\section{Results}

The technique used for interpreting data and calculating the fundamental average sizes and the dispersion indicators was the statistical method featured in specialized works.

In order to analyse and interpret the results obtained, I have used the statistical-mathematical data processing methods, because they facilitate the description of the phenomenon, on one hand, and they put order in the thoughts and they enable the data interpretation and analysis process, on the other.

Interpretation is represented by the critical appraisal of the data obtained in the research. The collecting of wrong data would lead, obviously, to false findings, while the incorrect processing of data would also lead to wrong conclusions.

Using as elements of reference the results of physical tests, the experiment has highlighted the students' acquisitions throughout the research in terms of motor skills.

Discussions and conclusions. Upon comparing the results obtained at the initial testing and at the final testing, it is worth underscoring the following differentiations:

After analysing the results obtained in the two tests for event 1 -standing long jump, I note that in the initial testing, the group average value was $0.84 \mathrm{~m}$, while in the final testing the average was 0.94 ; thus, the progress was $0.10 \mathrm{~m}$. Upon analysing the value of the variability coefficient in the two tests, it may be stated that group homogeneity is relatively good, with a VC ranging between 33.43 and $30.68 \%$. (Graph 1)

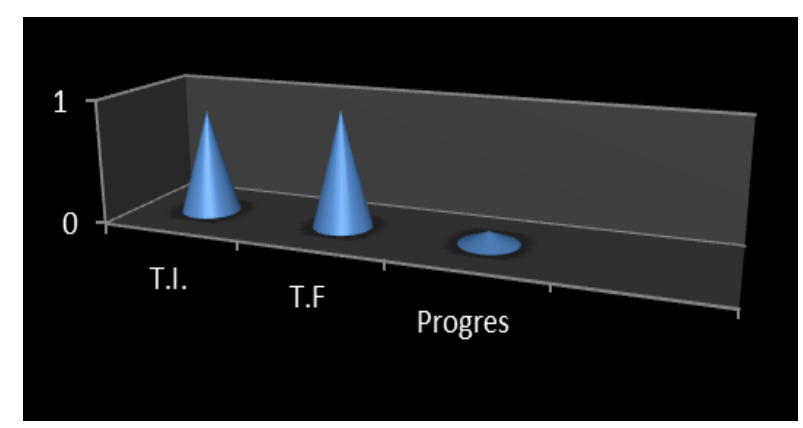

Graph 1. Standing long jump

For event 2 - speed run, the following results were obtained: in the initial testing $11.33 \mathrm{sec}$. and in the final testing $10.56 \mathrm{sec}$, the progress being $0.77 \mathrm{sec}$. (graph 2). The value of the variability coefficient in the two tests ranges between $13.12 \%$ (in the initial testing) and $7.75 \%$ (in the final testing), which stands to show a very good group homogeneity for this event. 


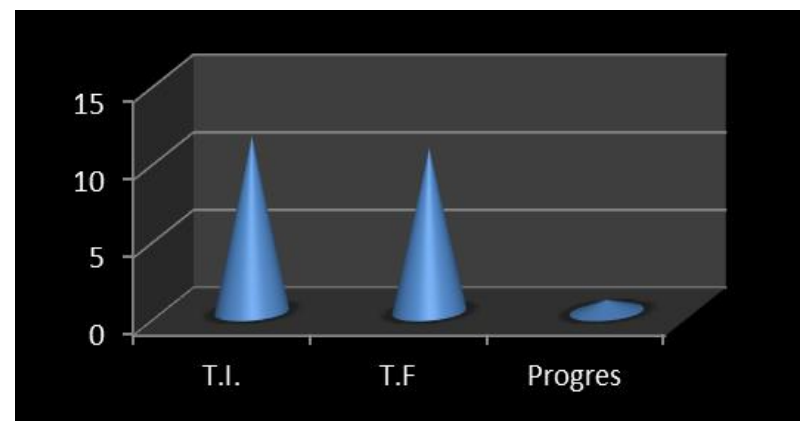

Graph 2. Speed run

By assessing the outcomes obtained for event 3 $5 \times 10 \mathrm{~m}$ relay, we have found an average of $17.86 \mathrm{sec}$ in the initial testing and of $17.11 \mathrm{sec}$ in the final testing, thus achieving a progress of $0.75 \mathrm{sec}$. The value of the variability coefficient is below $6 \%$, which represents a very good group homogeneity for this event.

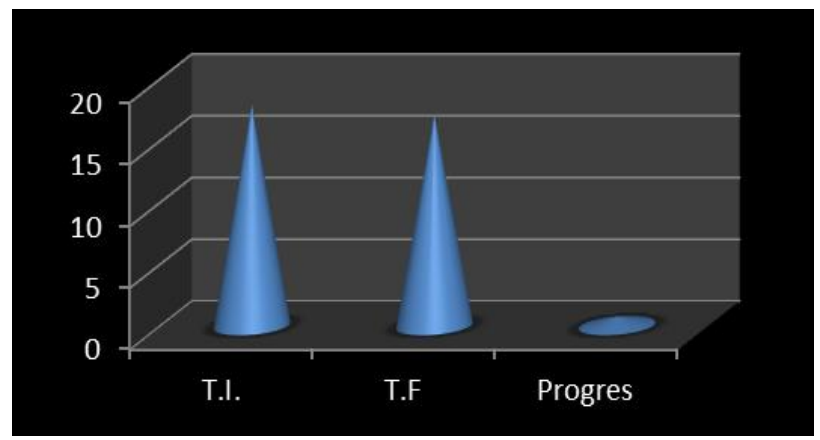

Graph 3. 5x10 m relay

For event 4 - tennis ball throw, the following results were recorded: in the initial testing, the group average value was $11.65 \mathrm{~m}$, and in the final testing the average was $15.82 \mathrm{~m}$, which proves a progress of $4.17 \mathrm{~m}$. After appraising the values of the variability coefficient $(30.13 \%$ in the initial testing and $32.97 \%$ in the final testing), it may be stated that group homogeneity was good for this event.

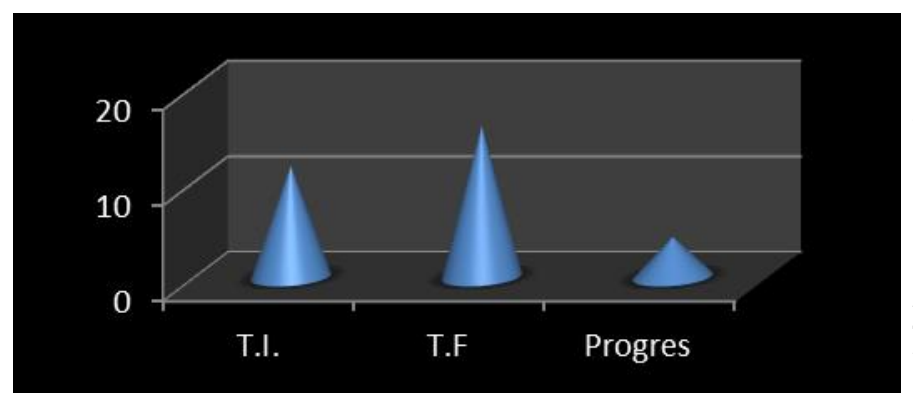

Graph 4. Tennis ball throw

\section{Conclusions}

After conducting this study, the following conclusions may be drawn:

-It was necessary to approach this topic in order to bring into discussion a reality that has been scarcely featured in the scientific literature.

-The efficiency of the methodology applied was proven in all situations and for all research samples; hence, the experimental endeavour had significant results for the parameters considered in the study.

-The research conducted has included reference data and most of them have a practical use, and the research endeavour has an applicative value.

-The paper may be used as a source of information by those who are in charge with the management of the instructive and educative process or by those within the field of children's psychomotor training. -By comparing the results obtained by the subjects included in the study, I have noted progresses for all four events.

-The positive outcomes were influenced by the following aspects :

-use of dynamic games, mainly during the physical education class;

-combination of verbal methods - exposition, explanation; intuitive methods - demonstration, execution appraisal; and practical methods practicing;

-short, clear and concise explanations;

-global demonstration followed by movement description and explanation;

-selection of captivating games, adapted to students; -presentation and observation of certain rules meant to avoid injuries;

-appreciation for even the smallest progress accomplished by the students and encouragements for students struggling with clumsiness;

-correction of mistakes found in the execution of certain procedures by the students;

-teacher's demonstration represents an example to follow for the students; thus, they want to execute the drills as accurately as possible.

In conclusion, if you respect the age and individual particularities of students, as well as the didactic principles, if you select proper training games and if you conduct the planned activity systematically with responsibility and love for children and for the profession of teacher, then results will definitely come. 


\section{References}

1. Arcan P., Ciumăgeanu D. (1980). Copilul deficient mintal, Editura Facla, Timişoara.

2. Cozma T., Gherguț A. (2000). Introducere în problematica educaţiei integrate, Iaşi, Editura Spiru Haret.
3. Gherasim C. (2003). Jocuri în lecţia de educaţie fizică, Editura Altfel, Iaşi.

4. Ionescu S. (1975). Adaptarea socio-profesională a deficienților mintali, Editura Academiei, București.

5. Zazzo R. (1979). Debilităţile mintale, Editura didactică şi pedagogică, București, 